\title{
The Utilization of Community Radio as a Form of Social Engineering to Society in Disaster-Prone Areas
}

\author{
Siti Hadiyati Nur Hafida ${ }^{1}$, Sutama ${ }^{2}$, Harun Joko $\mathrm{P}^{3}$ \\ \{shnh421@ums.ac.id\} \\ 1,2Department of Geography Education, Surakarta Muhammadiyah University, Surakarta, Indonesia \\ ${ }^{3}$ Department of Indonesian Language Education, Surakarta Muhammadiyah University, Surakarta, \\ Indonesia
}

\begin{abstract}
Disaster is not a new phenomenon. Disasters can be minimized if disaster information is easily received by people in disaster-prone areas, but often people in disaster-prone areas receive the information too late. Community radio is one of the society-based disaster information media. This study aims to determine the utilization of community radio as a form of social engineering to the society in disaster-prone areas. This research is a qualitative study with research respondents are the manager of the Lintas Merapi FM community radio and the society. The results showed that the utilization of the Lintas Merapi FM community radio was effective, because there was a balance between society needs, understanding, response and adaptation to community radio. People are able to adapt well to the Lintas Merapi FM community radio so that the community radio program activities will be adjusted to the society needs. The role of the Lintas Merapi FM community radio in social engineering can be seen through the changes in people's attitudes and behavior in dealing with the disasters. Society independence in dealing with the disasters can reduce victims of disasters.
\end{abstract}

Keywords: Disaster, Community Radio, Disaster-Prone

\section{Introduction}

Natural disasters are a natural occurrence which is difficult to be avoided by humans due related to natural conditions, so that no one can resist the natural disaster. Volcanic eruption is one example of natural disasters that often occur in Indonesia, especially Java. According to the Volcanologist Directorate in 2010 (Eva Banowati, 2012: 49), Java Island is the island with the highest number of active volcanoes in Indonesia that are 35 volcanoes. One of the active volcanoes in Java is Merapi Volcano. Based on data from BNPB, the number of victims caused by Merapi Volcano eruption in 2010 was 275 people.

The large number of victims of the Merapi Volcano disaster did not affect the public's fear to live on the slopes of Merapi Volcano. Since there are still many people living on the slopes of Mount Merapi, we must be balanced it with a high level of disaster preparedness. If a region with a high level of danger and vulnerability however, society preparedness for disasters is also high so the impact of the disaster can be reduced (Ali Ghufron Mukti in Agus Indiyanto, 2012: 98). Disasters will always occur but the society must always be prepared for 
disasters. Disaster preparedness shows that the society is able to increase its capacity to deal with disasters (Lelisa Sena Kifle W / Michael, 2006: 4). Although now there are many disaster detection tools and technology, however if it is not balanced with consciousness and disaster alert behavior, the utilization will not be optimal (Kwartarini Wahyu, et al in Agus Indiyanto, 2012: 137). The enhancement of society preparedness in facing the disasters can encourage the social change in society. Social change is a phenomenon that occurs as a form of society adaptation to the changes that occur so that it can encourage the establishment of society development (Cigdem Kagitcıbası, Zeynep Cemalcilar, etc, 2009: 10). People in disasterprone areas often experience social problems associated with attitudes and beliefs that unwittingly can change people's lives, these social issues can be solved through social engineering (planned social change). Social changes to societies in disaster-prone areas can be encouraged through the use of an infrastructure, especially infrastructure related to communication and information. Every social system will create its own reality through communication based on specific differences (Kristof van Assche, Martijn Duineveld, etc, 2011: 35). One of the infrastructures that can be utilized in a disaster situation is community radio. Radio infrastructure can be used as an Early Warning System (EWS) because during a disaster situation, all communication media will experience interference and only radio can still be used to disseminate disaster information. Radio is one of the media that provides life knowledge, freedom and transfer of capabilities from one generation to another (Kevin Howley, 2005; Sudhamshu Dahal, 2013: 44). Radio is very effective as a communication tool because of portability, affordability and the ability to reach many listeners, even in poor areas with very little infrastructure (Peter Kibe Ngugi and Charles Kinyua, 2014: 233). Radio infrastructure that is closely related to society social change is community radio. Community radio infrastructure is radio infrastructure operated by the society, for the society and by the society (Louie Tabing, 2002: 11). Community radio is a typical radio station that is characterized by programs produced by the local people, in local languages or dialects, and talks about relevant local issues (Ramnath Bhat, 2014: 13-14).

Community radio is considered as the most suitable medium to help the lower middle class to change in a better direction (Lawrence Naaikuur \& Africanus L Diedong, 2014: 175). The development of community radio shows that there is progress in information technology and changes in the development paradigm towards a more participatory (Chapman et al in Seidu Al-Hassan et al, 2011: 1). The first thing that needs to be understood from a community radio is it is more related to the society and less radio related (Niamh Gaynor \& Anne O'Brien, 2011: 437). Society participation in managing community radio will be the key to manage community radio. Participation means engaging in the whole activity (active) and not only participating (passively) (Masduki, 2004: 148). Community radio is different from private radio which only emphasizes economic benefits, community radio aims to advance the surrounding society so that without participation from the surrounding society, all activities from community radio will be bland and insignificant. Community radio is not only focused on broadcasting but also active in social services and cares about problems that occur in the society (Dede Lilis, M Rochim, Nova Yuliati, 2016: 74).

The utilization of community radio will be influenced by cognitive representation or mental representation. Mental representation is the individual's comprehension to something (Smith \& Queller, 2003). According to Kunda (1999), an understanding of everything depends on a set of concepts of beliefs, and theories as well as goals and feelings they have. The understanding will be realized through people's attitudes and behavior when making a decision. The understanding will be influenced by the existence of information differences by each individual, attitudes differences and individual interests (Su Rito Handoyo, et al, 2011). 
Society understanding in the infrastructure utilization will be related to the society's response and adaptation to existing infrastructure. Society response can be seen through perceptions, attitudes and behavior of the society (J.A.R Jatil \& Asep Mulyadi, 2015).

The use of community radio can provide many benefits because the entire activities programs on community radio will be adjusted to the society needs. Community radio can play a supporting role not only in achieving targets, but also can contribute to create new development opportunities (Kaberi Gayen, 2012: 38). This development opportunity can be utilized by the society to be better prepared in facing disasters.

\section{Method}

This research is a qualitative research that aims to analyze the utilization of community radio as a form of social engineering to societies in disaster-prone areas. This research was conducted in the Lintas Merapi FM community radio through direct surveys. Respondents in this study were managers of the Lintas Merapi FM community radio and societies around the Lintas Merapi FM community radio. The utilization of community radio as a form of social engineering can be analyzed through the needs, understanding, response and adaptation of the society to community radio infrastructure. Society that understands disaster will need a media that can be used as a medium for disaster information and communication. The existing media and technology often will experience disruptions due to disasters, which can encourage people to be panic. Community radio is a society-based disaster information and communication media, therefore, community radio management will depend on society activities in managing community radio. The better the response and adaptation of the society to community radio, the social changes in society can be realized.

\section{Result and Discussion}

\subsection{Utilization of Community Radio}

The utilization of an infrastructure will always related to the need, understanding, response and adaptation of the society towards the infrastructure. People can respond to existing infrastructure by giving positive, negative and even skepticism response. Negative and skepticism response will make infrastructure to destruct, because without the society, the infrastructure will not run optimally.

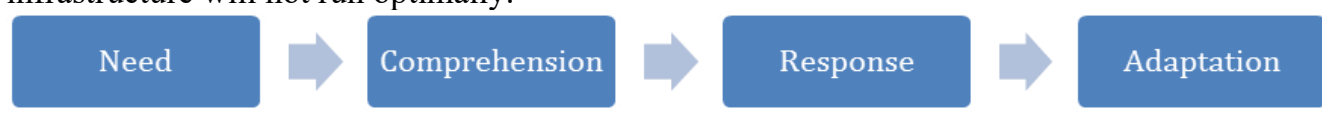

Fig 1. Aspects of Utilizing Community Radio

The society of Sidorejo Village, Kemalang District, Klaten Regency has a very high level of information and communication needs. This is due to the location of Sidorejo Village which is located at an altitude of 900 meters above sea level and only $4.5 \mathrm{~km}$ from the peak of Merapi Volcano. This condition makes society access to information and communication (especially related to disasters) to be slower than other regions in lowland areas. The difference in access to information and communication can lead to information disparities. The main society that is supposed to get information related to disasters obtains disaster information slower compared to other regions.

The Sidorejo Village's people already knew about the disaster around them and the impact of the disaster. The understanding of disasters encourages people to always get disaster information so the information needs of the disaster are very high. The high needs for disaster 
information can encourage society preparedness in the facing the disasters. If they received better information, the preparedness of the society will be better.

Lintas Merapi FM community radio has been operating since 2001 but the utilization at the beginning of the establishment was still very limited. The society still did not understand the role of community radio so that all community radio management was only delegated to community radio managers. The large number of victims of the Merapi Volcano eruption in 2010 encouraged the people of Sidorejo Village to utilize the Lintas Merapi FM community radio more optimally. The society began to realize the importance of disaster information after the society experienced the impact of the eruption disaster. Societies are facing uncertainty because they do not know what will happen to their lives and environments. This experience eventually encouraged the society to reconsider the importance of community radio as an early warning system during a disaster situation.

The society responds positively to the existence of the Lintas Merapi FM community radio. The society agrees that community radio is an information media needed in disasterprone areas. Although the development of technology is very fast, the information and communication media often experience disruptions during disaster situations. Radio is a medium of information and communication that can still be used even during a disaster situation, therefore, the society begins to adapt to the Lintas Merapi FM community radio. The society adaptation can be seen through active society involvement in the management of the Lintas Merapi FM community radio.

People are not only a listener of the Lintas Merapi FM community radio; they are also involved as a disaster information seeker, broadcaster, operator and even manager of the Lintas Merapi FM community radio. Active community involvement can encourage the realization of more interesting programs on the Lintas Merapi FM community radio. The societies know what they need so that they always try to distribute the latest news.

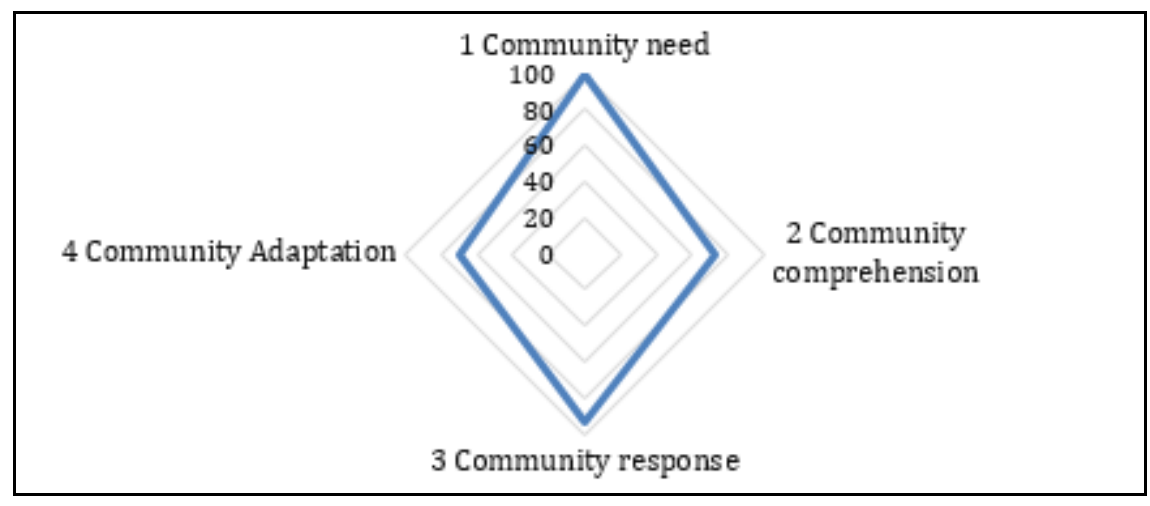

Fig 2. The Utilization of the Lintas Merapi FM Community Radio

\subsection{Community Radio as a Form of Social Engineering}

The people around the Lintas Merapi FM community radio are able to adapt well to all community radio activities. People in disaster-prone areas are often regarded as weak and disadvantaged societies. The existence of these assumptions then encouraged the community 
to utilize the Lintas Merapi FM community radio not only as a medium for disaster information and communication. The people begin to create economic activities that are able to improve the economy of the society, such as: entrepreneurship training, cultural arts training, etc. as well as disaster simulation activities so that the people are more prepared in facing the disasters. The activities are the result of collaboration with several sponsors (government and private).

The people began to participate in activities held by community radio actively. Community radio managers always try to hold off-air activities that can be followed by all of people, so that the whole society can experience significant social change. One of the social changes that are formed after the use of community radio is the attitudes and beliefs of the community. Community radio managers plan these social changes in order to minimalizing disaster victims, so social changes that occur are the result of planning (social engineering). The attitude changes are shown by the society through the disaster preparedness of each individual. The people no longer wait for disaster information from the government, because often disaster information announced by the government to the society in disaster-prone areas is late received. The delay in distributing disaster information from the government to the society can make more disaster victims.

The society installed an early warning system in a traditional and modern way so that whenever a condition changes in Mount Merapi, the society will immediately know it. The people do not need to feel confused about disaster information because all existing disaster data and information are the result of direct observation. The societies and community radio managers are also able to develop disaster information networks through social media, so that disaster information will be more complete. Community radio managers also provide $\mathrm{Wi}-\mathrm{Fi}$ in the Lintas Merapi FM community radio station so that disaster information that has been analyzed by the people can be directly spread via the internet. The provision of Wi-Fi can encourage changes in people's knowledge, so that the people are able to access information (health, education, politics, religion, tourism, entertainment, etc.) more easily. The changes in community knowledge can encourage the realization of social change in society. The societies can adjust their values, norms, attitudes, and beliefs with the development of science and technology. In 2010, the cause of many victims of the Merapi Volcano eruption is because people more prioritize to save their livestock and property than their self-salvation. The people began to understand that when a disaster happens, saving themselves and their families is a most important thing to do. Livestock and property are not the main aspects that must be saved. Routine disaster simulation activities are carried out so that people more understand about the importance of saving themselves and their families.

The most unique use of community radio related to social engineering is the change in the environment management that more safe and comfortable. This is demonstrated through the installation of several CCTVs in Sidorejo Village which are operated by community radio managers. The CCTV will monitor the condition of Merapi Volcano and the village environment so that society security can be guaranteed. This security system is able to encourage people to be more ready and alert in any conditions, including crime. If there is theft of property, the thief will be easily arrested because it is recorded on CCTV. Lintas Merapi FM community radio is capable of being well utilized by the people so that it can encourage the realization of social change for societies in disaster-prone areas. 


\section{Conclusion}

The community radio is a very effective medium to encourage social change in society. It is because community radio is managed by the society, by the society, and for the society so that people know better what they need. The utilization of community radio will be effective if there is a balance between society's needs, understanding, response and adaptation. However, because community radio management is entirely carried out by the society often community radio will experience setbacks and even cannot operate anymore. Considering the role of community radio in disaster-prone areas is very important, it is necessary to have in-depth research on the sustainability model of community radio in disaster-prone areas so that societies in disaster prone areas are well prepared for disasters.

\section{References}

[1] Agus Indiyanto dan Arqom Kuswanjono 2012 Konstruksi Masyarakat Tangguh Bencana (Bandung: Mizan Pustaka)

[2] Cigdem Kagitcibas1, Zeynep Cemalcilar, etc 2009 Children of Rural to Urban Migration: An Integrative Intervention for Adaptation to Social Change International Society for the Study of Behavioural Development 1(55): 10-14

[3] Dede Lilis, M Rochim and Nova Yuliati 2016 Voluntarism as Social Capital of Community Radio Management: a Case Study in Jarik III Cirebon Komunitas International Journal of Indonesian Society and Culture 8(1): 73-84

[4] Eva Banowati 2012 Geografi Indonesia (Yogyakarta: Ombak Publisher)

[5] J.A.R. Jatil and Asep Mulyadi 2015 Study of Space and Public Response to Aviation Activities Around of Runway Airport Husein Sastranegara Geography Education 15(2): 66-72

[6] Kevin Howley 2005 Community Media: People, Places and Communication Technologies. (England: Cambridge University Press)

[7] Kaberi Gayen 2012 Community Radio in Bangladesh The Policy and The Spirit Media Asia 39(1): 32-39

[8] Kunda, Z 1999 Social Cognition: Making Sense of People (Cambridge, MA: MIT 32)

[9] Lawrence Naaikuur and Africanus L Diedong 2014 Core Dimensions of Community Radio in Action: The Case of Ghana Global Media Journal African Edition 8(2): 175206

[10] Lelisa Sena and Kifle W/Michael 2006 Disaster Prevention and Preparedness Jimma University and Ethiopia Public Health Training Initiative

[11] Louie Tabing 2002 How to do Community Radio: A Primer for Community Radio Operators UNESCO

[12] Masduki 2004 Perkembangan dan Problematika Radio Komunitas di Indonesia Jurnal Ilmu Komunikasi 1(1): 73-86

[13] Niamh Gaynor and Anne O'Brien 2011 Because It All Begins with Talk: Community Radio as a Vital Element in Community Development Community Development Journal 47(3): 436-447

[14] Peter Kibe Ngugi and Charles Kinyua 2014 The Concept and Philosophy of Community Radio Stations in the Kenyan Context $J$ Mass Communicat Journalism 5(1): $233-241$ 
[15] Ramnath Bhat 2014 Module 1 Community Radio: An Introduction (New Delhi: CEMCA \& BECIL)

[16] Seidu Al-hasaan, Alhassan Andani and Abdulai Abdul-Malik 2011 The Role of Community Radio in Livelihood Improvement: The Case of Simli Radio The Journal of Field Actions Science Reports 5: 1-6

[17] Smith, E.R \& Queller, S 2003 Mental Representations. In a Tesser \& N.Schwarz (Eds) Blackwell Handbook of Social Psychology: Intraindividual processes (Malden, MA: Blackwell) pp 111-133.

[18] Su Rito Hardoyo, dkk 2011 Strategi Adaptasi Masyarakat dalam Menghadapi Bencana Banjir Pasang Air Laut di Kota Pekalongan (Yogyakarta: MPPDAS UGM Press)

[19] Sudhamshu Dahal 2013 Power, Empowerment and Community Radio: Media by and for Women in Nepal Women's Studies International Forum 40: 44-5 